\title{
Handbook of Florida Water Regulation: Introduction ${ }^{1}$
}

\author{
Michael T. Olexa, Luke D'Isernia, Laura Minton, Dulcy Miller, and Sarah Corbett ${ }^{2}$
}

\section{Preface}

This handbook is designed to provide an accurate, current, and authoritative summary of the principle Federal and Florida laws that directly or indirectly relate to agriculture. This handbook should provide a basic overview of the many rights and responsibilities that farmers and farmland owners have under both Federal and Florida laws as well as the appropriate contact information to obtain more detailed information. However, the reader should be aware that because the laws, administrative rulings, and court decisions on which this handbook is based are subject to constant revision, portions of this publication could become outdated at anytime.

Several details of cited laws are also left out due to space limitations.

This handbook is distributed with the understanding that the authors are not engaged in rendering legal or other professional advice, and the information contained herein should not be regarded as a substitute for professional advice. This handbook is not all inclusive in providing information to achieve compliance with the Federal and Florida laws and regulations governing water protection. For these reasons, the use of these materials by any person constitutes an agreement to hold harmless the authors, the Florida Cooperative Extension Service, the Institute of Food and Agricultural Sciences, and the University of Florida for any liability claims, damages, or expenses that may be incurred by any person as a result of reference to or reliance on the information contained in this handbook.

\section{General Purpose}

This handbook is designed to act as a compass through the maze of statutes, regulations, and potential liabilities that identify the current mass of water protection law. Created for readers with no prior experience in law, it is designed as a necessary first step in recognizing which agricultural activities merit special attention because of their groundwater and surface water implications. It also provides an introduction to the crucial agencies and statutes that govern the realm of water protection.

The law in this area is evolving rapidly as concern for the environment increases. Because the sources and goals of the existing environmental statutes vary, the law as a whole has not developed

1. This is EDIS document FE580, a publication of the Food and Resource Economics Department, Florida Cooperative Extension Service, Institute of Food and Agricultural Sciences, University of Florida, Gainesville, FL. Published December 2005. Please visit the EDIS website at http://edis.ifas.ufl.edu.

2. Michael T. Olexa, Professor, Food and Resource Economics Department, Florida Cooperative Extension Service, Institute of Food and Agricultural Sciences, University of Florida, Gainesville, FL; Director, Agricultural Law Center, University of Florida, Gainesville, FL; and Chair, Agricultural Law Committee of The Florida Bar. Luke D'Isernia, former student (graduated cum laude in 2005), Levin College of Law, University of Florida, Gainesville, FL. Laura Minton, Attorney, Dean, Mead, Egerton, Bloodworth, Capouano, and Bozarth, Orlando, FL. Dulcy Miller, attorney, Foley and Lardner, LLP, Orlando, FL. Sarah Corbett, Attorney, Florida Second District Court of Appeal, Lakeland, FL.

The Institute of Food and Agricultural Sciences (IFAS) is an Equal Opportunity Institution authorized to provide research, educational information and other services only to individuals and institutions that function with non-discrimination with respect to race, creed, color, religion, age, disability, sex, sexual orientation, marital status, national origin, political opinions or affiliations. U.S. Department of Agriculture, Cooperative Extension Service, University of Florida, IFAS, Florida A. \& M. University Cooperative Extension Program, and Boards of County Commissioners Cooperating. Larry Arrington, Dean 
with systematic precision. This presents a confusing array of overlapping, unclear, and occasionally even contradictory mandates. Consequently, this area of law often presents a formidable barrier to both lawyers and laypersons struggling to determine their exact rights and responsibilities. Perseverance is necessary, though, as penalties or liabilities in some instances may be quite substantial.

This work should not be regarded as the final word on any of the topics discussed because this is not a comprehensive study. Rather, the reader should view this publication as a means to determine the areas in which to seek more information and as a brief directory of agencies that can help answer more specific questions. State and federal agencies are unquestionably the best targets for specific questions, as they are in close touch with both the formal and practical considerations of the areas they regulate. Contact Information for addresses and/or telephone numbers of the agencies and divisions is listed in the Appendix (FE615). These agencies can provide more information on the topic, answer specific questions, and often supply free literature.

This handbook's effectiveness can only be enhanced by the submission of ideas and suggestions about the scope and quality of its coverage.

Comments regarding any areas that may have been omitted, but deserve inclusion, would be particularly valued. Reader feedback is a necessary ingredient to complete any successful future editions. With this in mind, please send any comments or suggestions to the following address:

Michael T. Olexa, PhD, JD

UF/IFAS Agricultural Law Center

Post Office Box 110240

University of Florida

Gainesville, FL 32611-0240

\section{Acknowledgments}

The authors are indebted to the personnel of both state and federal agencies who provided their time and advice in the preparation of this handbook. The authors are especially indebted to Richard Budell of the Office of Agricultural Water Policy of the Florida Department of Agriculture and Consumer Services for providing funds for the development of this publication. 